\title{
$\mathrm{Ni}-\mathrm{Ti}$ 超弾性合金の水素放出挙動に及ぼす 陰極水素チャージ条件の影響*
}

\author{
小田哲郎**，小川登志男 ${ }^{* * *}$ ，酒井潤一**, \\ ** 早稲田大学 基幹理工学研究科 \\ *** 木更津工業高等専門学校 機械工学科 \\ 早稲田大学 理工学術院 各務記念材料技術研究所
}

\section{Effect of Cathodic Hydrogen Charging Conditions on Hydrogen Desorption Behavior of Ni-Ti Superelastic Alloy*}

\author{
Tetsuro Oda**, Toshio Ogawa*** and Jun'ichi Sakai**, ${ }^{*}$ \\ ** Faculty of Science and Engineering, Waseda University \\ *** Department of Mechanical Engineering, National Institute of Technology, Kisarazu College \\ Kagami Memorial Laboratory for Materials Science and Technology Waseda University
}

We investigated the effect of hydrogen absorption conditions on hydrogen desorption behavior of Ni-Ti superelastic alloy with cathodic hydrogen charging in $0.9 \% \mathrm{NaCl}$ solution. The amount of desorbed hydrogen at low temperature $\left(\sim 200{ }^{\circ} \mathrm{C}\right)$ increased with increasing cathodic current density. It is likely that the increment of the amount of desorbed hydrogen at low temperature was due to the increment of the amount of hydrides formation. Vickers hardness in the vicinity of the surface of the alloy also increased with increasing cathodic current density. This is probably due to the hydrides formation in the vicinity of the surface of the alloy. These results suggest that hydrogen concentration in the vicinity of the surface of the alloy increased with increasing cathodic current density, i. e., increasing the amount of generated hydrogen per unit time, thereby causing the acceleration of hydrides formation.

Key words : Nickel-Titanium superelastic alloy, hydrogen absorption, hydride, thermal desorption analysis

\section{1. 緒}

\section{言}

$\mathrm{Ni}-\mathrm{Ti}$ 合金の水素吸収及び水素脆化特性は, 㓌極水素 チャージによって水素を吸収させる方法で調べられてき た ${ }^{11-11)}$ 。また，陰極水素チャージ時の溶液の温度や $\mathrm{pH}$ を変えることにより本合金の水素放出挙動は大きく変化 する ${ }^{12,13)}$. 水素脆化の研究では, 昇温脱離水素分析によ り材料中の水素量を測定するとともに, 水素放出プロフ アイルから材料中の水素の存在状態を解析する手法が主 に用いられている。したがって, 上述した既往の研究に 打りる水素放出挙動の変化から, 水素吸収条件により本 合金中の水素の存在状態が異なるということが示唆され る.

また，本合金の水素脆化機構としてさまざまな説が提 唱されている ${ }^{3,5), 77-9)}$. 例えば，本合金の水素脆化には マルテンサイト変態の影響が大きいことが報告されてい $3^{3), 77}$. Ni-Ti 超弹性合金の水素脆化特性は，マルテンサ イト変態に伴う水素の存在状態の動的な変化に大きく影 響を受けると考えられている7)。一方著者らは, Ni-Ti超

* 第 62 回材料と環境討論会(福岡, 2015 年)で発表

** ₹ 169-8555 東京都新宿区大久保 3-4-1(3-4-1, Okubo, Shinjuku-ku, Tokyo, 169-8555 Japan)

*** ₹ 292-0041 木更津市清見台東 2-11-1(2-11-1, Kiyomidai-higashi, Kisarazu, 292-0041 Japan)

† ₹ 169-0051東京都新宿区西早稲田 2-8-6(2-8-6, Nishiwaseda, Shinjuku-ku, Tokyo, 169-0051 Japan)
弾性合金の水素脆化特性には，水素吸収により合金中に 形成される水素化物の存在が大きく影響することを明ら かにした ${ }^{14)}$. したがって, 本合金中の水素化物の形成と 水素放出挙動の関連性を明らかにすることは，本合金の 水素脆化機構解明の一助となる.

そこで本研究の目的は, Ni-Ti超弾性合金に扔ける水 素化物の形成及び水素放出挙動に及ほす水素吸収条件, 特に陰極水素チャージ電流密度の影響を明らかにするこ ととした．著者らの報告 ${ }^{14)}$ から，単位時間当たりの吸 収水素量の増加に伴って, 水素化物の形成量も増加する ことが示唆される。したがって本研究では, 陰極水素于 ヤージ電流密度を変化させることにより水素化物の形成 量を変化させ, Ni-Ti 超弾性合金の水素化物の形成量と 水素放出挙動の関連性について解析を行った.

\section{2. 実 験 方 法}

試料には市販の直径 $0.50 \mathrm{~mm}$ の $\mathrm{Ni}-\mathrm{Ti}$ 超弾性合金ワイ ヤ材 $(\mathrm{Ni}: 56.0$ mass\%, Ti:balance)を用いた。試験溶液 には $0.9 \mathrm{mass} \% \mathrm{NaCl}$ 水溶液を用いた。

$50 \mathrm{~mm}$ に切り出した試料の表面を $\mathrm{SiC}$ 研磨紙 600 番で 磨き, アセトン洗浄した後, 室温 $\left(25^{\circ} \mathrm{C}\right)$ にて陰極水素于 ヤージを行った。昇温水素脱離分析に抢ける $25 \sim 600{ }^{\circ} \mathrm{C}$ の温度域の放出水素量を約 350 mass ppm で統一するた めにチャージ条件はそれぞれ条件 $\mathrm{A}: 2 \mathrm{~A} / \mathrm{m}^{2} \times 7 \mathrm{~h}$, 条件 $\mathrm{B}: 10 \mathrm{~A} / \mathrm{m}^{2} \times 1 \mathrm{~h}$ 及び条件 C: $20 \mathrm{~A} / \mathrm{m}^{2} \times 0.5 \mathrm{~h}$ とした。吸 収水素量の測定には質量分析型昇温脱離水素分析装置 
（(株）アルバック製，TDS-KU-S）を用い，昇温速度は 100 ${ }^{\circ} \mathrm{C} / \mathrm{h}$, 測定範囲は $25 \sim 600{ }^{\circ} \mathrm{C}$ とた。 また，水素化物の 同定には X 線回折装置((株)リガク製, RINT-RAPID)を 用い, 管電圧 : $40 \mathrm{kV}$, 管電流 : $20 \mathrm{~mA}$, target: $\mathrm{Cu}$ とした. 試料内の水素分布を調べるために, ビッカース硬さ試験 を行った．荷重は $0.2 \mathrm{~N}$ ，負荷時間は $15 \mathrm{~s}$ とした.

\section{3. 実験結果及び考察}

各チャージ条件下で水素チャージを行った試料の水素 放出曲線を Fig. 1 に示す. 条件 A, B 及び C で水素チャー ジを行った試料の放出水素量はいずれもおよそ 350 mass ppm とほぼ同等であったが，水素放出ピーク温度は 300 , 280 及び $260{ }^{\circ} \mathrm{C}$ であり, チャージ電流密度の増加により水 素放出ピークは僅かに低温側にシフトした。また，各チャ ージ条件下で水素チャージを行った試料の水素放出曲線 における $200{ }^{\circ} \mathrm{C}$ 以下での放出水素量は，それぞれ 9,60 及び 92 mass ppm であり, チャージ電流密度の増加によ り $200{ }^{\circ} \mathrm{C}$ 以下での放出水素量は増加する傾向が確認され た(Fig. 2). したがって, 低温での放出水素量の増加に

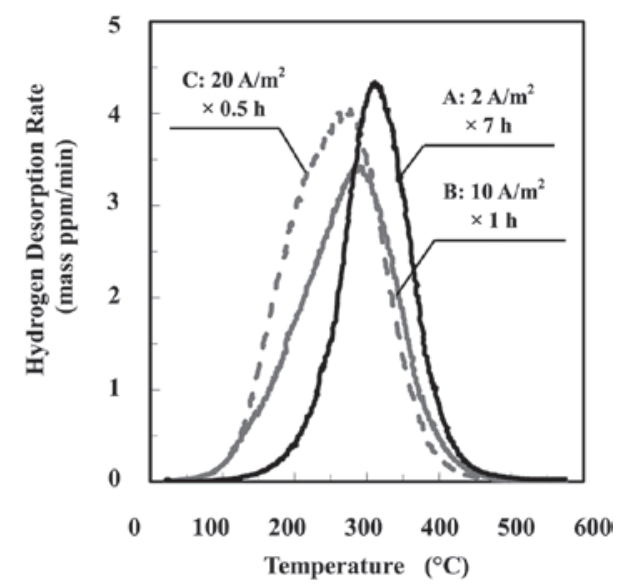

Fig. 1 Hydrogen thermal desorption curves for specimens charged with $2 \mathrm{~A} / \mathrm{m}^{2}$ for $7 \mathrm{~h}, 10 \mathrm{~A} / \mathrm{m}^{2}$ for $1 \mathrm{~h}$ and $20 \mathrm{~A} / \mathrm{m}^{2}$ for $0.5 \mathrm{~h}$.

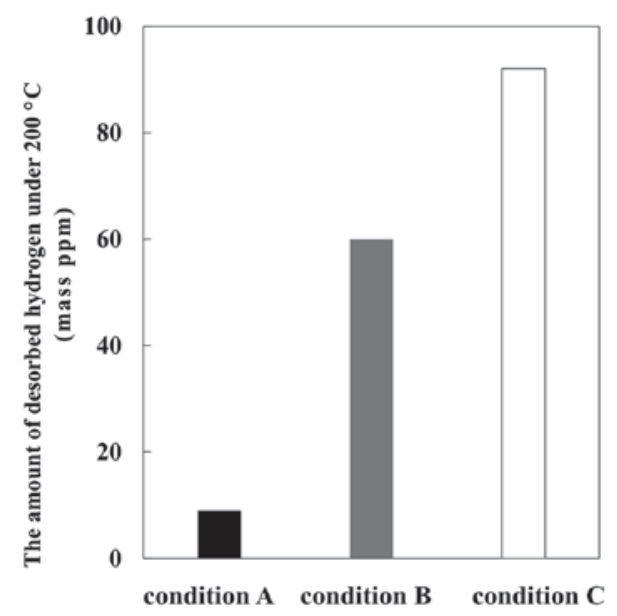

Fig. 2 The amount of desorbed hydrogen under $200{ }^{\circ} \mathrm{C}$ for specimens charged with $2 \mathrm{~A} / \mathrm{m}^{2}$ for $7 \mathrm{~h}, 10 \mathrm{~A} / \mathrm{m}^{2}$ for $1 \mathrm{~h}$ and $20 \mathrm{~A} / \mathrm{m}^{2}$ for $0.5 \mathrm{~h}$.
伴い, 増加した水素に対応するピークが結合されること で, ピーク温度が低温側にシフトした。

各チャージ条件下で水素チャージを行った試料の X 線 回折パターンを Fig. 3 に示す. 条件 A で水素チャージを 行った試料では水素化物に対応するピークは検出されな かったのに対し, 条件 B 及び Cで水素チャージを行っ た試料では水素化物 $\mathrm{TiNiH}$ (正方晶 ; $a=0.6221 \mathrm{~nm}, c=$ $1.2363 \mathrm{~nm})^{15)}$ に対応するピークが検出された。

本合金中に形成される水素化物は室温で分解すること が明らかになっている ${ }^{5), 14)}$ 。したがって，本合金中に水 素化物として存在する水素は, 低温域において放出され ると考えられる，そこで，本合金内で水素化物として存 在する水素と水素放出挙動との関係を確認するために, 水素化物の形成が認められた条件 B 及び C で水素チャ ージを行った後に, $100{ }^{\circ} \mathrm{C} \times 0.5 \mathrm{~h}$ 加熱保持した試料にお ける水素化物の有無を X 線回折によって調べた。 その結 果を Fig. 4 に示す. 条件 B 及び Cで水素チャージを行 った両試料において, 水素化物に対応するピークは検出 されず，水素添加を行っていない as-polished 材と同様 の回折パターンを示した。したがって，本研究において

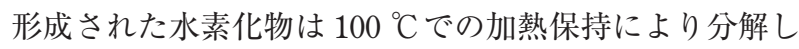
たと考えられる。本研究における水素吸収環境以外の水 素吸収環境においても，本合金は吸収水素量が増加する と低温側での放出水素量が増加するという傾向がみられ る $^{12), 13)}$. また, $\alpha$-Ti 中に水素化物として存在していた水 素は, 水素化物の分解温度近傍では試料からほとんど放

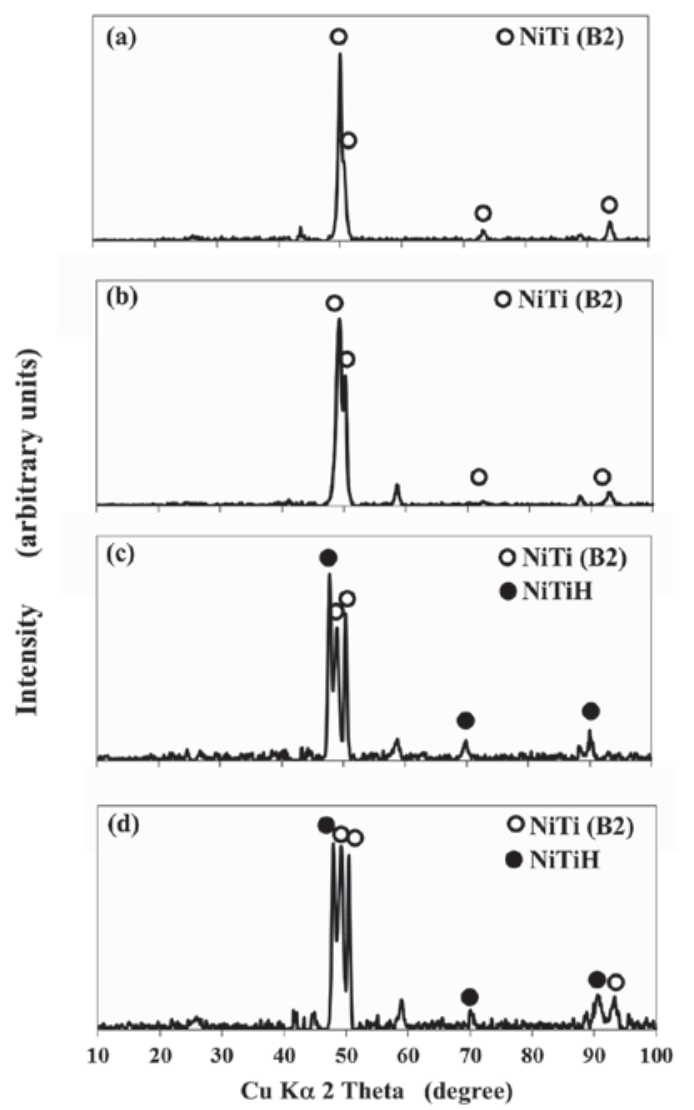

Fig. 3 XRD patterns of (a) non-charged specimen and specimens charged with (b) $2 \mathrm{~A} / \mathrm{m}^{2}$ for $7 \mathrm{~h}$, (c) $10 \mathrm{~A} / \mathrm{m}^{2}$ for $1 \mathrm{~h}$ and (d) $20 \mathrm{~A} / \mathrm{m}^{2}$ for $0.5 \mathrm{~h}$. 


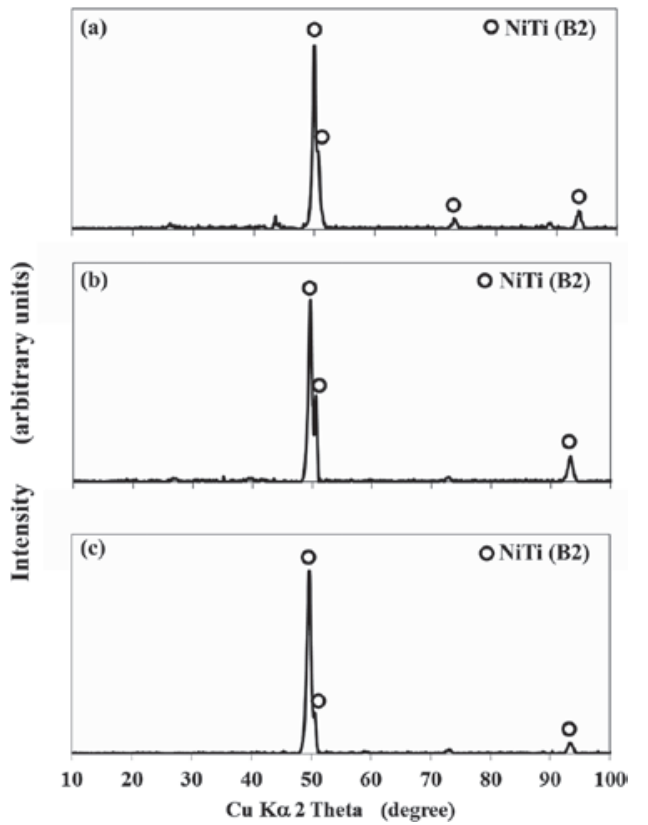

Fig. 4 XRD patterns of (a) non-charged specimen and specimens heated at $100{ }^{\circ} \mathrm{C}$ for $0.5 \mathrm{~h}$ after charged with (b) $10 \mathrm{~A} / \mathrm{m}^{2}$ for $1 \mathrm{~h}$ and (c) $20 \mathrm{~A} / \mathrm{m}^{2}$ for $0.5 \mathrm{~h}$.

出されない ${ }^{16)}$. これは, 水素化物の分解により生じた水 素原子の多くが, 試料内部に拡散もしくは固溶するため であると考えられている。本合金中に形成された水素化 物の分解は $100{ }^{\circ} \mathrm{C} て ゙$ 確認されたが, Fig. 1 に示したよう に $100{ }^{\circ} \mathrm{C}$ 近傍における水素放出はほとんどみられなかっ た。これは, 水素化物の分解により生じた水素原子が試 料外部へ放出されるには, 水素化物の分解に要した以上 の熱エネルギーが必要であるためと考えられる。また, $200{ }^{\circ} \mathrm{C}$ 以上の温度域になると, 条件 A で水素チャージを 行った試料の放出水素量の増加が顕著になることから, 水素化物の分解により生じた水素は $200{ }^{\circ} \mathrm{C}$ 以下の温度域 において試料外部へ放出されると考えられる，一方，水 素化物の形成が確認されなかった条件 A で水素チャージ を行った試料においても僅かながら $200{ }^{\circ} \mathrm{C}$ 以下での水素 放出を確認したことから, $200{ }^{\circ} \mathrm{C}$ 以下で放出される水素 は水素化物の分解によって生じた水素だけではなく, 本 合金中に存在していた固溶水素も僅かではあるが含まれ ていると推察される. 以上のことから, 電流密度の増加 に伴い増加した $200{ }^{\circ} \mathrm{C}$ 以下で放出された水素の大部分 は, 水素化物として存在していた水素に対応していると 考えられる。

また, 試料内の水素濃度分布を調べるために, 各チャー ジ条件下で水素チャージを行った試料のビッカース硬さ試 験結果を Fig. 5 に示す。ここで, 条件 B 及び C で水素チ ヤージを行った試料の表層から $10 \mu \mathrm{m}$ の位置の硬さの值 についてはばらつきが大きかったことから, ビッカース 硬さ試験結果(繰り返し数 10 回)をヒストグラムにして 整理した(Fig. 6).なお, Fig. 5 における表層から $10 \mu \mathrm{m}$ の位置の硬さの值は, Fig. 6 に示したヒストグラムの中 央值を採用した。条件 A で水素チャージを行った試料で は, 試料表層から中心部にかけて硬さはなだらかに減少 した. Fig. 3 に示したように，条件 A で水素チャージを 行った試料では水素化物の形成が確認されなかったこと

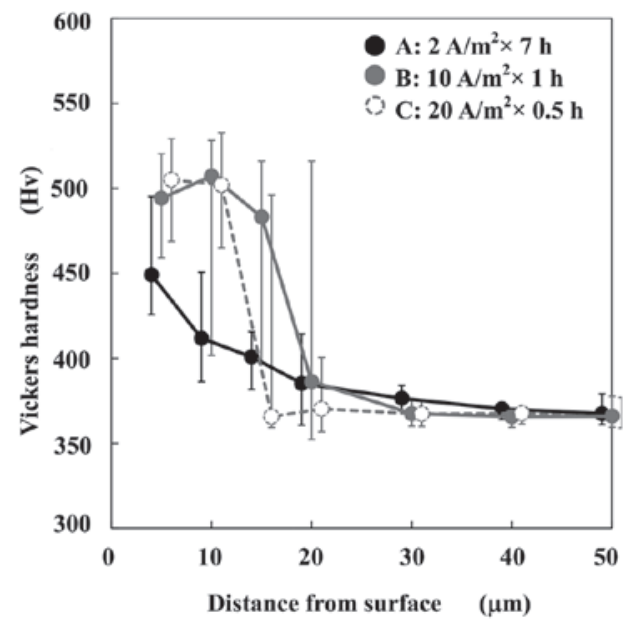

Fig. 5 Vickers microhardness of non-charged specimen and specimens charged with $2 \mathrm{~A} / \mathrm{m}^{2}$ for $7 \mathrm{~h}, 10 \mathrm{~A} / \mathrm{m}^{2}$ for $1 \mathrm{~h}$ and $20 \mathrm{~A} / \mathrm{m}^{2}$ for $0.5 \mathrm{~h}$

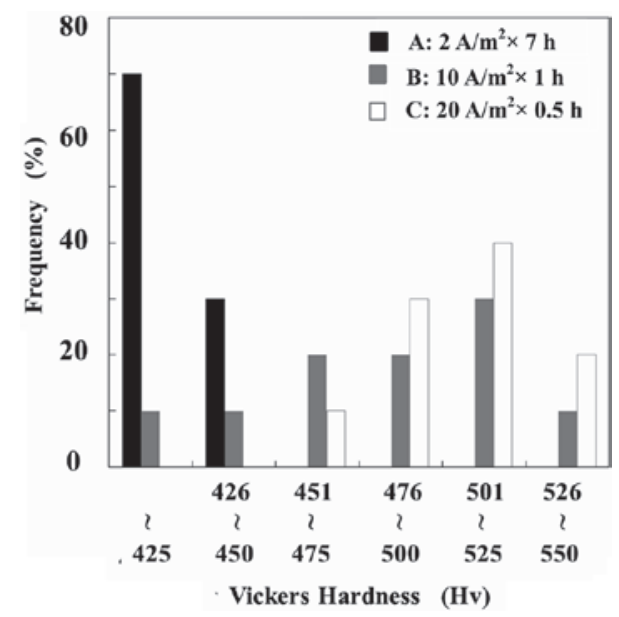

Fig. 6 Frequency distribution of Vickers microhardness at the position of $10 \mu \mathrm{m}$ from surface of specimens charged with $10 \mathrm{~A} / \mathrm{m}^{2}$ for $1 \mathrm{~h}$ and $20 \mathrm{~A} / \mathrm{m}^{2}$ for $0.5 \mathrm{~h}$.

から，この硬さの上昇は固溶水素による固溶強化に起因 すると考えられる。一方, 条件 B 及び C で水素チャー ジを行った試料の表層付近における硬さはいずれもおよ そ $500 \mathrm{Hv}$ となり，条件 A と比べて高い值を示した。 ま た，条件 $\mathrm{B}$ 及び $\mathrm{C} て ゙$ 水素チャージを行った試料の表層 からそれぞれ 20 及び $15 \mu \mathrm{m}$ の位置において，急激な硬 さの減少がみられた。

条件 $\mathrm{B}$ 及び Cで水素チャージを行った試料の表層付近 における硬さの上昇と水素化物の形成との因果関係を確 認するために, 水素チャージ後の試料側面を $\mathrm{SiC}$ 研磨紙 600 番を用いて研削した後にX 線回折による水素化物の 同定を行った。研削後の試料を, X 線回折による水素化 物の形成の確認をすることで, 深さ方向における水素化 物の形成を確認するとともに，水素化物の形成範囲が推 定できる. 条件 B 及び C で水素チャージを行った試料の 径を $5 \mu \mathrm{m}$ ピッチで研削した試料の X 線回折パターンを それぞれ Fig. 7 及び 8 に示す. 条件 B での水素チャージ の場合, $10 \mu \mathrm{m}$ 研削した試料では水素化物の形成が確認 されたのに対し，15 $\mu \mathrm{m}$ 研削した試料では水素化物の形 


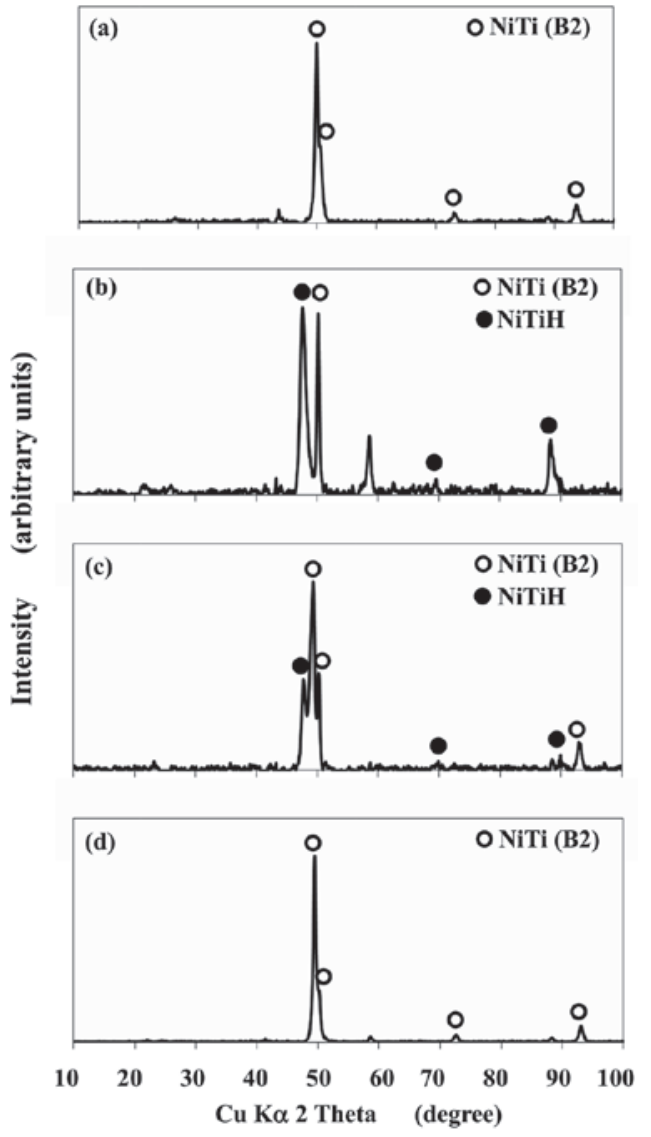

Fig. 7 XRD patterns of (a) non-charged specimen and specimens grinded to (b) $5 \mu \mathrm{m}$, (c) $10 \mu \mathrm{m}$ and (d) $15 \mu$ $\mathrm{m}$ after $10 \mathrm{~A} / \mathrm{m}^{2}$ for $1 \mathrm{~h}$.

成は確認されなかった。一方, 条件 Cでの水素チャージ の場合, $5 \mu \mathrm{m}$ 研削した試料では素化物の形成が確認され たのに対し, $10 \mu \mathrm{m}$ 研削した試料では水素化物の形成は 確認されなかった。

水素化物の形成範囲を推定する上で，X線の侵入深さ を $10 \mu \mathrm{m}$ として研削距離に加えると, 条件 B 及びC で 水素チャージを行った試料の水素化物の形成範囲はそれ ぞれおよそ $15 \sim 20$ 及び $10 \sim 15 \mu \mathrm{m}$ であると見積もられ た。これは，条件 B 及び Cで水素チャージを行った試 料において急激な硬さの上昇がみられた領域と一致す る。したがって，条件 B 及びC C゙水素チャージを行っ た試料の表層に扔ける急激な硬さの上昇は, 水素化物の 形成に起因していると考えられる，純Tiに打いて緻密 な水素化物 $\mathrm{TiH}_{1.971}$ (面心立方晶; $a=0.444 \mathrm{~nm}$ ) が形成さ れると，母材の硬さが上昇することが知られている ${ }^{17), 18)}$. 本研究に打いて形成された水素化物 $(\mathrm{TiNiH})$ の格子定数 は母相と比べて大きくなる ${ }^{19)}$ ため, Fig. 5 に示したよう に試料表層では水素化物の形成により硬さが増加したと 推察される.

ここで，条件 A で水素チャージを行った試料では固溶 強化によってのみ硬さの上昇がみられたことから (Fig. 4), $500 \mathrm{Hv}$ 以下は固溶強化による硬化であると仮定した. Fig. 6 より, 条件 B と比べて条件 C で水素チャージを行 った試料は硬さの值のばらつきが小さく，全ての值が 450 $\mathrm{Hv}$ 以上を示した．また，条件 Cで水素チャージを行った

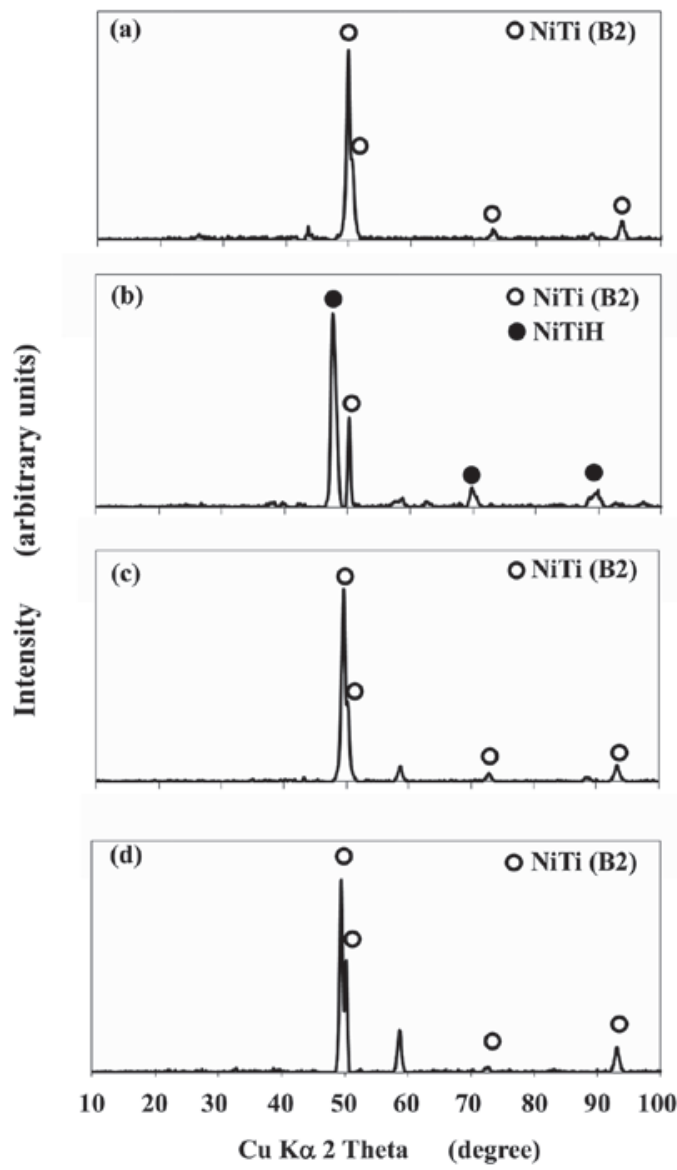

Fig. 8 XRD patterns of (a) non-charged specimen and specimens grinded to (b) $5 \mu \mathrm{m}$, (c) $10 \mu \mathrm{m}$ and (d) $15 \mu$ $\mathrm{m}$ after $20 \mathrm{~A} / \mathrm{m}^{2}$ for $0.5 \mathrm{~h}$.

試料については, 全 10 回の繰り返し試験のうち 501〜 $550 \mathrm{Hv}$ の值を示した割合は $60 \%$ であったのに対し，条件 B で水素チャージを行った試料では 40\%であった．した がって, 条件 B 及びCで水素チャージを行った試料では, 水素化物の形成量が異なると考えられる.

条件 B と C において水素化物の形成量に差が生じた原 因として, チャージ電流密度の違いが挙げられる. 条件 $\mathrm{B}$ と比べて条件 C の電流密度は 2 倍であるため, 条件 C で水素チャージを行った試料のほうが単位時間当たりの 発生水素量が 2 倍多いと考えられる。また，各条件下で 水素チャージを行った際の電位の経時変化を Fig. 9 に示 す. 条件 B で水素チャージを行った試料では打よそ-1.2 V vs. SCE で電位が安定したのに対し, 条件 Cで水素于 ヤージを行った試料ではおよそ-1.3 V vs. SCE で安定し た．水素チャージ時の電位が卑であるほど, 試料表面の 吸着水素濃度が高くなることが従来報告されている ${ }^{20)}$. したがって, 条件 B と比べて条件 Cで水素チャージを 行った試料表面における吸着水素濃度が高くなったた め, 試料表層の水素濃度も高くなったと推察される。 そ の結果, 条件 Cで水素チャージを行った試料では水素化 物の形成が促進され，他条件と比べて $200{ }^{\circ} \mathrm{C}$ 以下に扔け る放出水素量が増加したと考えられる. 


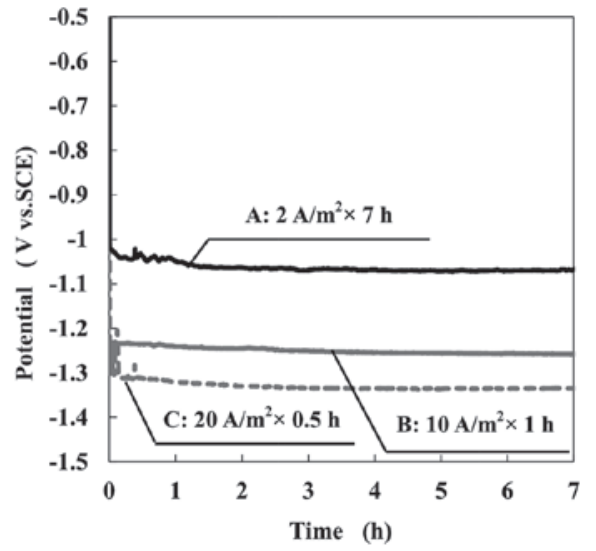

Fig. 9 Changes in corrosion potential of specimens charged with $2 \mathrm{~A} / \mathrm{m}^{2}$ for $7 \mathrm{~h}, 10 \mathrm{~A} / \mathrm{m}^{2}$ for $1 \mathrm{~h}$ and $20 \mathrm{~A} / \mathrm{m}^{2}$ for $0.5 \mathrm{~h}$.

\section{4. 結}

\section{言}

$\mathrm{Ni}-\mathrm{Ti}$ 超弾性合金の水素放出挙動に及ぼす水素吸収条 件, 特にチャージ電流密度の影響を検討し, 以下のこと を明らかにした。

1) チャージ電流密度の増加に伴い, 水素放出ピークは低 温側にシフトし, $200{ }^{\circ} \mathrm{C}$ 以下で放出される水素量が増 加した。

2) チャージ電流密度を $10 \mathrm{~A} / \mathrm{m}^{2}$ 以上にすると, 水素化物 の形成が認められ, チャージ電流密度の上昇に伴い, 水素化物の形成量も増加した.

3) $200{ }^{\circ} \mathrm{C}$ 以下で放出される水素の大部分は, 本合金中に 形成された水素化物に対応していた。

参 考 文 献

1) K. Yokoyama, K. Hamada, K. Moriyama and K. Asaoka,
Biomater., 22, 2259 (2001).

2) K. Yokoyama, K. Hamada and K. Asaoka, Mater. Trans., 42, [1] 142 (2001).

3) K. Yokoyama, S. Watabe, K. Hamada, J. Sakai, K.Asaoka and M. Nagumo, Mater. Sci. Eng. A, 341, 93 (2003).

4) K. Yokoyama, M. Tomita, K. Asaoka and J. Sakai, Scripta Mater., 57, 394 (2007).

5) K. Yokoyama, T. Ogawa, K. Takashima, K. Asaoka and J.Sakai, Mater. Sci. Eng. A, 466, 106 (2007).

6) M. Tomita, K. Yokoyama, K. Asaoka and J. Sakai, Mater. Sci. Eng. A, 476, 312 (2008).

7) K. Yokoyama, M. Tomita and J. Sakai, Acta Mater., 57, 1875 (2009).

8) F. Gamaoun and T. Hassine, J. Alloys Compd., 615, S680 (2014).

9) F. Gamaoun, M. Ltaief, T. Bouraoui and T.B. Zined, J. Intell. Mater. Syst. Struct., 22, 2053 (2011).

10) N. Wade, Y. Adachi and Y. Hosoi, Scripta Metallurgica et Materialia, 24, 1051 (1990).

11) Y. Adachi, N. Wade, Y. Hosoi, J. Japan. Inst. Metals, 54, 525 (1990).

12) M. Tomita, K. Yokoyama and J. Sakai, Corrsion Sci., 50 , 2064 (2008).

13) A. Ota, Y. Yazaki, K. Yokoyama and J. Sakai, Mater. Trans., 50, [7] 1848 (2009).

14） T. Ogawa, T. Oda, K. Maruoka and J. Sakai, J. Mech. Mater. Eng., 10, 11 (2015).

15) J. L. Soubeyroux, D. Fruchart, G. Lorthioir, P. Ochin and D. Colin, J. Alloys Compd., 196, 127 (1993).

16) T. Ogawa, K. Yokoyama, K. Asaoka and J. Sakai, J. Alloys Compd., 396, 269 (2005).

17) H. Koketsu, Y. Taniyama, A. Yonezu, H. Cho, T. Ogawa, M. Takemoto and G. Nakayama, Zairyo-to-Kankyo, 55, 205 (2006).

18) J. J. Xu, H.Y. Cheung and S. Q. Shi, J. Alloys Compd., 436, $82(2007)$.

19) H. Hagi, M. Mizuno and T. Ibe, J. Surf. Finish. Soc. Jpn., 48, 337 (1997)

20) R. Schmidt, M. Sclereth, H. Wipf, W. Assmus and M. Mullner, J. Phys. Condens. Matter, 1, 2473 (1989).

(Manuscript received December 11, 2015; in final form February 18, 2016)

\section{要 旨}

$\mathrm{Ni}-\mathrm{Ti}$ 超弾性合金の水素放出挙動に及ぼす水素吸収条件の影響について調査した．陰極水素チャージ時の電 流密度の増大に伴い, 低温 $\left(\sim 200{ }^{\circ} \mathrm{C}\right)$ における放出水素量は増加した. この低温における放出水素量の増加 は, 水素化物の形成量の増加に起因していると考えられた. また, 陰極水素チャージ時の電流密度の増大に伴 い, 試料表層の硬さは上昇した。これは, 試料表層に形成された水素化物に起因していると推察された。 した がって, 陰極水素チャージ時の電流密度, つまり単位時間の発生水素量の増加に伴い, 試料表層の水素濃度 が高くなり，水素化物の形成が促進されたと考えられた。

キーワード Ni-Ti 超弾性合金, 水素吸収, 水素化物, 昇温脱離分析 